\title{
Cultural and Ethnic Characteristics of Sikhs in Afghanistan
}

\author{
Mujtaba Arify \\ Department of Archeology and Anthropology, Social Sciences, Kabul University, Kabul, Afghanistan \\ Email: arify2014@gmail.com
}

How to cite this paper: Arify, M. (2021). Cultural and Ethnic Characteristics of Sikhs in Afghanistan. Advances in Anthropology, 11, 25-35.

https://doi.org/10.4236/aa.2021.111003

Received: November 24, 2020

Accepted: February 4, 2021

Published: February 7, 2021

Copyright (c) 2021 by author(s) and Scientific Research Publishing Inc. This work is licensed under the Creative Commons Attribution International License (CC BY 4.0).

http://creativecommons.org/licenses/by/4.0/

\begin{abstract}
Afghanistan is a land that has lived together with small ethnic tribes and minorities throughout history, and in terms of history, these tribes have spoken different dialects, had their own customs, traditions and beliefs, and by studying the appearance and their anatomical structure more carefully, this difference can be considered from the ideological point of view, natural geographical structure and neighborly relations with neighboring countries. But these ethnic minorities are referred by different names, including Sikhs and Hindus living in the country who faced all kinds of oppression and suffering of the time, and most of them endured it and considered this land as their homeland.
\end{abstract}

\section{Keywords}

Ethnic, Beliefs, Sikhs, Hindu, Minority

\section{Introduction}

The evidence and information obtained before the spread of Islam in the land now called Afghanistan, lived Zoroastrians, Buddhists and Hindus. Today's Hindus and Sikhs are the remains of the same Hindus which more than 1400 years ago they migrated to this land. By coursing the time, they have been able to carry out their activities as a citizen of this land and play a role in all matters which from then until today, this process continues with many ups and downs. Despite of all the problems and lack of attention of the officials in political, commercial, economic and social affairs and the beliefs of the Hindu and Sikhs in Afghanistan, this gentle and noble people did not leave their homeland and continued to live in this land and also them proud of living in this land too. Despite of being all the problems in the research carried out by institutions and in- 
stitutions, little attention has been paid to the recognition and introduction of this Afghan people.

\section{Historical Background of Sikhs in Afghanistan}

Hindu and Hinduism in southern Afghanistan have date back more than 3000 years. The first immigrants to migrate from Central Asia to Afghanistan and then to India were Vedas. The Vedas established the Vedic religion, then Hinduism, and later Buddhism. Cities in southern Afghanistan were Hindu during the Morya dynasty. During the reign of Ashoka, the son of Chanderagopta Murray, Buddhism replaced Hinduism in Afghanistan; but a large number of Hindus lived in Afghanistan. Buddhism was destroyed in Afghanistan after Arab rule, but Hinduism remained up to now, a number of this group live in this soil. During the reign of Mohammad Dawood Khan, the number of Hindus and Sikhs reached one hundred thousand. After the start of the civil war, about 30,000 of them emigrated and lived in the cities of Kabul, Jalalabad, Paktia, and Charikar. There are now about 700 families, totally 4000, who are living as a miserable life under pressure from Muslims. They previously had two members in the Afghan parliament. They do not have any representative in parliament now.

Mehr Chand Verma is an Afghan Hindu who served as Deputy Minister of Finance until 1984 and then as Economic Advisor to the Afghan Council of Ministers.

Ji Sang was one of the first Sikhs in Afghanistan to be elected in the twelfth term of the Afghan Parliament. Sonaram Talwar was one of the first documentarians in Afghanistan that were a Hindu.

Chat Ram Sati, the dominant drummer in Afghanistan, was also a Hindu. He has been a member of Radio Amateur Orchestra of Afghanistan and has played drums for many of the songs of Ahmad Zahir, Zahir Hovida, Rahim Jahani, Mashour Jamal, Salma, Jila, Nashenas and a number of other singers. San Tuk Sang was one of the first colonels of the Afghan Hindu army. Rajani Paran was one of the first speakers on Radio Afghanistan who later sang also were Hindu. Now, I do not know why some of us consider Hindus to be separate from other Afghans. Why do we take their rights, why do we harass their men, women and children?

Hindu and Sikh children are reportedly being harassed by Muslim children in public and private schools. They are beaten, they hear ugly words, their money and other personal belongings are stolen (Chahardehi, 1984).

For example, one or two important people and personalities of this people can be mentioned throughout the history of Afghanistan. First, Nandrala Ghaznavi was one of the famous poets of the Ghaznavi Yan period who wrote Sufi poems, and another person was Naranjandas, the Minister of Finance of Shah Amanullah Khan period. He had a noble daughter named Rado, who was always his father's friend and companion and could open a way to the court as well. Poets have described beauty and perfection as two poems, one of which was composed by Nashenas (singer) too. 
Chen Kapoor, the founder of banks and one of the founders of National bank of Afghanistan, was also a Hindu. The draft law of the bank, the economy and the designer of the bank notes of that time were among his important functions was Hindu. Professor Bal McNas Das was one of the first professors of the Faculty of Medicine of Afghanistan was a Hindu. Pranat was one of the first and best singers of Afghanistan who was also Hindu.

According to statistics compiled by Ashor (2001), author of "We Are the Ancient Inhabitants of this Land", from the sacred centres of Hindus and Sikhs are as follow. There are 15 temples and Daramsal in Kabul and 18 units in Kandahar, 10 units in Nangarhar, Logar, and Laghman, 1 unit in Jalalabad and 4 units in Ghazni. In Bamyan, he also mentions the city's Buddhas as a source of worship. The Hindus lived in isolation and illegitimacy after the arrival of the Arabs. Years later, in 1900, Amir Abdul Rahman Khan allowed the Hindus to rebuild the temple at the slope of Asmayee Mountain, whose deed was in the name of the late Mr. Doni Chand, one of the Hindu elders of Kabul, was organized and registered in the municipal office. This made Hindu temples and Afghan Sikhs legally identifiable, not as legal property but as personal property. Due to religious prejudice, Hindu temples do not have equal rights with mosques and noble shrines. And they do not have equal privileges in relation to the product of electricity, drinking water and purity product. Asmayee and Shivaki Temples are among the most historic Hindu temples in Afghanistan.

The Sikhs lived in Afghanistan for many years. But due to various problems, they did not gain the status of a real citizen and against them always socially discriminated.

\section{Origin of Hindus and Sikhs in Afghanistan}

According to the literature of ethnographic research and studies, it is very little that we can determine a specific and accurate history in terms of the origin and knowledge of a people, which is why Hindus and Sikhs's origin in Afghanistan still are not clear, but there are different narratives and views about them.

\section{The Scholars of the Sikh's Religion}

Nanok did not believe in idols, temples, mosques, and churches. He said: God should not be limited because everything belongs to God and God can be found everywhere and is manifested in every place and has no special place. Nanok knew all the people and beings as creatures, and was a reincarnation of the creator and he denied. He had the rosary of Muslims in his hand and Indian cross on his neck (Rezayee, 2001).

Nanok called the God truth. He used to say that God is the only one who can be called by any name (Heyoum, 1990).

Happiness and attainment of Nerwana are the same as induction in remembrance. He considered the Maya, or the illusory form of the world which is existing in Hinduism action and reaction to some extent accepted. Made allowable 
eating of the meat to his followers and prohibited austerity and idolatry, he also forbade the Cast system and the number of marriages (Tawqifi, 2004).

Nanok said: The Supreme Being has been manifested in various places and thoughts and beliefs through various images and beliefs. But wherever it is and whenever it is, I am afraid to be read. Only God Almighty is omnipotent, and if a title should be given to him, he should be called Harry, which in the language of Punjabi means kind. He did not count sacred to the water. He did not believe in to the incarnation of human being to the God. Guru Nanok took advantage of the actions and promises of the Islamic Sufis and was influenced by their teachings. He took wearing leather clothes from Islamic Sufis who which Indian's Sufis wore and even their elders being very famous by wearing leather clothes and Nanok copied their cloth custom as well. Sacred places did not have any special meaning for him. Though for this kind of behaviours he goes to pilgrimages of Kabaa to the all religions who performance religious customs and prohibited from idolatry (Rezayee, 2001).

Nanok opposes smoking. Alcohol is prohibited. A woman does not have the authority and cannot get divorce. If the woman is unhappy, with her consent, the other woman can be chosen. The wealth must be transferred to the boy and deaths must by burn and its trashes must be drop down into the continuous water. Not to eat cow meat and slaughtering animals should be done by only one stroke (Chahardehi, 1984).

\section{Summary of Sikh's Cultural Ceremonies}

\subsection{The Rules and Customs of the Temple}

All the people who come to the temple must wear a hat, and if their head are naked and there is no hat, they must at least cover themselves with their headscarves. Every individual of Sikhs who come to mosque must be bowing down from 1 meter distance beside the Sacred Book and go to the prostration and once again do bowing down unless change their location and then turning away and sit in the line of participants. And during speech of their mullah the crowd in the mosque observes pure silence and does not even whisper.

The Sikhs go to the temple in the morning and at night to perform their duties, and their morning prayer have higher value than the night prayer, and all the prayers are performed with pleasant music. Each member of this sect is allowed to repeat the word (vaguer) which means (God is pleasing).Their night prayer begins at seven o'clock in the afternoon and ends at nine o'clock. Instead of the sermon, the history of the gurus' life is read (Jehati, 2001).

Everyone who enters into the temple puts a portion of the cash in front of the Sacred Book on the carpet, from which the expenses of the temple are covered. Religious leadership is not reserved for some people, and anyone can be the leader or mullah without the relevant classes and intelligence of the leader. After the prayer, the halva or ajil prayer which has not been vowed before in front of the Sacred Book and a cloth is drawn on it, is divided among the attendees that 
everyone should eat their share and if anyone do not eat all their share, he will insult others and be reprimanded (Rezayee, 2001).

And in my eyes, in Daramsal of Karte Parwan when all the Sikhs from both men and women come out of the place of prayer everyone should eat milk with a cake which has been prepared beforehand in the courtyard of the mosque.

The Morning Prayer sometimes continues from six o'clock in the morning until nine o'clock, and wherever the Sacred Books is located it is the place of the Sikhs's qibla and the night prayer is held individually, but the Morning Pray is in community. If a person is not able to offer the Morning Pray in congregation in the mosque, he can stand and pray toward the mosque but in the congregational prayer, it is obligatory to go to the Sacred Booke beforehand. As Narindar Mullah, in the Daramsal of Karte Parwan added, we do not set a time for prayer or worship, but a Sikh person both male and female must worship for two hours and forty minutes (2:40) during one day (in 24 hours). Whether he prays or worship calling the name of God is obligatory, and during this period the human mind should be calm from work and life and no one should disturb their worship (Interview with Narindar Mullah at the Daramsal of Karte Parwan, 2006).

\section{Daramsal}

"Daramsal" is a Punjabi word used to refer to the place of religious education and the performance of Hindu (Sikhs) religious ceremonies. In this place, worship and ideological ceremonies, wedding ceremonies, etc. are performed as well. In addition, students of this ethnic group also learn their religious studies in this Daramsals.

\subsection{Wedding Ceremony}

In Afghanistan is the usual use of huge expenses in the wedding course. For many, this has led to a late marriage and has gone up in the urban society of marriage; but the citizens of the Afghan Sikhs and Hindu of Afghanistan are forbidden and they see only the satisfaction of the girl and the boy which is quite enough for the marriage. The marriage place of these Afghan citizens is in the Daramsal. The expenses of wedding are paid by boy and girl and if necessary, Daramsal also will help them.

The wedding ceremonies of Sikhs are as follow:

1) Recitation of part of the book (High Excellency Goru Gerant) called Puri which is confessed to the right to excellence.

2) The ceremony of the prayer and worship which is called Ardas is done to bring happiness and joy.

3) Spiritual person of Sikhs come to advice groom and bright and there is no take place divorce in this religion.

4) The recitation of Sacred Book is being done which revealed the instability of the world (Chahardehi, 1984).

You should take off your shoes when you go the mosque of the Sikhs and cover your head by piece of cloth or there is plenty piece of cloth in front of the 
mosque that entrances should put on their heads and then enter to the mosque. The groom will be entered with Span while a multi-month baby is in his arm. The music group started playing in honour of their entry and they launched the party. The child who was in the arm of the groom had a symbolic aspect (Popal, 2009).

There were two special halls for the Temple's ceremony to not disturb the worship of others. First, the elders of the two families come and shake with each other and then put a ring of flowers to their necks and so on take photos as memory and this will start from the elder family member up to the smallest one.

Then they all go to the holy room where there was a room in the hall that was completely white. That is, the walls and roofs were covered with white sets colour. On top of this room, there was a special place like the small altar which was covered with many flowers which spiritual man set there and accompany all the customs with the music. In presence of the man and Sacred Book women wear their Hejabs and men cover their heads with handkerchief and the groom and bright set together in front of this holy place and custom of agreement starts. Every one minute, music was cut off.

The holy man reads the Sacred Book and again closed it and groom and bright started to span the Holy place which were accompanied with the music. The reading of this book repeated for several times and as last read another pray. When reading the Sacred Book parents of bride and groom stood up to listen to prayers and bright started to tear slowly by slowly (Popal, 2000).

The last prayer was read by all and then they stood up and ring their fingers to each other which over the party. A man stood up and took the bowl of sweet halva and distributed for all. After that they whit room and bright and groom sit on the chair and all of the guest started to take photos with them as memory.

The bride and groom were wearing a blue red dress that was designed with beautiful stones. The cloth which was on their head were as much heavy as some time some else help them to hold it till decrease its weight (Internet Site).

Briefly, bride and groom after marital agreement hold each other's hand first circumambulation the Sacred Book and after performing four religious poem which recite it, also read loudly the happiness poem that called (High Excellency Anand) and audience in the temple sing it together with bride and groom. Rock is played through this party and then everybody stood up and located in front of Sacred Book and on that position they mention the names of bride and groom and ask all the happiness and joy of the world for them.

Marriage period is so short and meeting is prohibited and assigning day of marriage belongs to the girl family. All the relatives and friends are welcomed at the house of bride on the night of marriage. On the day of marriage couple's family presented at the mosque. For the performance of the marriage there is no document to be signed and written nowhere and dowry is assigned by the ability of bride family and do not write on the any document. Age of groom is 24 and girl's age is 18 and selection of marital is on the authority of parents (Amin, 
2007).

\subsection{Wedding Ceremony}

Sikhs have two Eid. One of them is birth of (Goru Nanok) which comes at the first day of the year and the other one is located on the descent of the religion which is memory holy victims of five person that called by the name of Eid (Yasaki) (Chahardehi, 1984).

Enormous and their religious Eid is the birth of Nanok. They present to the mosque 48 hours before and recite all the Sacred Book (Grant Saheb) with music. By this way everybody read it for one or two hours with music and so the Sacred Book is contained (1430) pages and in each hour (30) pages is being read but on other person just continue reading the book with loud voice and until morning of the Eid recitation of Sacred Book will be over. For the recitation of Sacred Book (Grant Saheb) they call Akand Pat and area of the mosque is called Guro Davar (Rezayee, 2001).

\subsection{Divorce Ceremony}

Actually, there is no divorce in Sikhs's religion. Sikhs are try that the relationship between a man and a woman should not be controversial and hostile but they want that they have a friendly relationship between each other and live in a peaceful atmosphere. In spite of all this, if their relationship breaks down; man easily invites their elder family members and elders of Daramsal to solve the issue or else he can affirm or say that she is not my wife anymore and the others agreed. On the opposite side, if women go to under the threat or pressure, she can also ask their elder family members and Daramsal as well in order to solve the issue and separate from her husband. After that both men and women have the permission to get married for the second time (Interview with Rawindar, one of citizens of Kabul city, year: 2006).

\subsection{Favorite Foods of Sikhs}

Hindus and Sikhs of Afghanistan always face problems for eating outside the house. Majority of them aren't carnivorous but the menus of Afghanian restaurants are full of meat. It's less seem that on the napkin of Afghani aren't exist meat. According to religious faith of these Afghan citizens eating of meat is illegal.

Darmander Sing, philosopher who lives in Deh Afghanan area of Kabul about this issue added to the news: "though meat is harmful for human but people of Afghanistan use it so much. When we go the restaurant with friends and ask vegetarian foods and foods which do not include meat in it, most of the time waiters of restaurant makes attractive laugh and says we do not have such foods. In this way, we don't have more than two options. Whether we ignore religions rules or go back to home hungry." (Ashor, 2001)

The favorite food of Hindus and Sikhs of Afghanistan opposite of Afghans is 
not Qabeli but their foods are Pakowra. On addition of this, the menus of these ethnic groups are the foods which do not content meat. Egg and onion are on their black lists of foods. Most of these menus are vegetables such us: Pakowra, cheese which its composition is potato, tomato and chips. Outside of the home Sikhs and Hindus cannot find their favorite foods. By this reason, they have minimum only one selection of the foods in the Kabul city. Ashak is the only food which its composition is not meat and can find it outside the house (khabarnama.net).

In the Kabul city these Afghan citizens come together at the hotel by the name of Espenzar for eating their Favorite food which can select it as well.

\subsection{Celebration of Visaak and Problem of Being Minority in Afghanistan}

On the 23rd of Hamal Vissak Celebration, religious day of Honud followers is celebrated by Sikhs and Hindus of Afghanistan in Nangarhar province. This celebration is held every year both in Kabul and Nangarhar cities. To be mentioned that due to insecurity Hindus and Sikhs of other provinces couldn't participate in this year's celebration. Celebration of Vissak is the historical celebration of Hindus but Sikhs flourish on this very much because this day is the origin of religion of Sikhs. On this day, in spite of other religious customs, Sacred Book is being recited as well. This celebration after 23rd of Hamal for three days is celebrated. Hindus and Sikhs in Afghanistan mainly lives at the cities of Kabul, Qandahar, Ghazni, Nangarhar, Kundoz, Khost, Paktia and Parwan and as informal statistic their population are more than 3000 people.

On the site of "Kabul Nat" which is belong to Sikhs of Afghanistan that the word "Vissak" has the root of sansacrite and its meaning is "birth of nature" and its used the same meaning both in Panjabi and Hindi as well. This word is the name of first of 12th month of Khorshedi and is plenty tidings of productions of agricultural and farmers by launching picnic start to get their productions of first season of the year. Also Indian people of "Gandahara" area in order to be thankful of this holy day, they wash their self on the near of rivers or big rivers as intellectual washing "Abhishka". On the other Indian religious countries are getting celebration from this Holy day. As in India beside the Ganga River and another rivers on this day, they do washing themselves.

It has been said that sect of Sikh about four centuries ago was created at the Panjab, India and its founder is Guro Nanok Davi Je. This sect had philosophy origin initially and its important message was peace and solidarity of various sects. The evolution steps of Sikh's sect was between 1469-1708 but after this date fundamental changes has been occurred which is exist up to now. Fundamental change on this sect was changing of its name into the "Sikh - Pantah" and adding suffix of "Sing" at the end of men and suffix of "Koor" or "Kawar" which means (Bi Bi) at the end of women's name. But Hindus and Sikhs in Afghanistan as minority ethnic and religious group are always face problems and also faced many historical pains. For the first time, Yaqoub Lais on his attack to 
Kabul destroyed all their temples and chapels and after that all Hindus and Sikhs couldn't use from their religious freedom and even now can't hold most of their religious and intellectual customs openly (Barzin, 2006).

At the history of Afghanistan not only Hindus and Sikhs but all other minority ethnic and religious groups had face many problems and frequently by issue of majority and minority has been created many social problems. Most of the current challenges of Afghanistan are on the issues of majority and minority. In spite of this, that political discipline of Afghanistan is democratic and democracy, but discrimination against minorities on all its kind as tribal, religious and cultural have rooted on the culture of the current at the moment as well and minorities are all face many kinds of discriminations like: political, social, and economical.

One of the most obvious discrimination against Hindu and Sikh's religious minority in Afghanistan was not known formally the rights of sending a representative from them to the country's parliament. In 2013, the members of the Afghan parliament rejected the right to choose a chair from 249 parliament seats to the Afghan Hindu, and President Hamid Karzai also confirmed this decision to parliament. According to this decision, Hindu and Sikh minority of Afghanistan were always deprived of the right to represent their delegator into the parliament. They argued that their citizenship is required to have a representative in parliament to defend their legal rights and establish their relationship with other governmental organs. In other cases, citizens of Afghanistan have prevented from burning their bodies, and many of their religious places and property have been usurped by them. This shows that despite the blow of democracy and human rights and citizenship rights, respect for religious minority rights in Afghanistan has not yet been institutionalized, and our society has been so far from believing to the religious pluralism, theological and cultural. But in a country where ethnic and religious minorities live, except mutual respect for each other and respect for freedom of opinion and belief, is there another way to solve social problems caused by ethnic and religious discrimination? How can it be spoken of the democratic system, but do not believe in minority rights and did not respect?

The history of Afghanistan shows that the choice of ethnic and religious conflict in state of interact and convergence has led to dangerous events that all of them suffered from them up to now, and at the same time no ethnic and religious groups could not remove the other group; Therefore, the only possible way to solve social and political challenges and its lack of continuity and accelerating it to the future is to accept ethnic, religious differences and respect for ethnic and religious minorities. Monopolistically thinking not only will not improve our situation, but will increase social tensions. The ethnic and religious differences in Afghanistan should be accepted as a social reality. The interest of our society is not that different ethnic groups are always should be in tension and their relationship be hostile; Social lawfully requires that we at the same time that we have different tendencies and beliefs, we must respect each other beliefs 
and try to have a peaceful coexistence. Respecting differences and diligence to pluralism can liberate our society from ethnic and religious conflicts and build a way to solve many social challenges (Godarzay, 1984).

Believing in political and social pluralism continues to create respect and tolerance between citizens of the country, and after that any other group will not harass the rights and interests of the other groups, and in state of that respecting and honors to the other's values and appreciate it and should find their problems solution by TED talk not to seek use guns or prefer conflict and disasters.

Hindus and Sikhs's of Afghanistan are one of Afghanistan's smallest ethnic minorities, giving away the belief and the rights and privileges of citizenship to them are their true rights, and the government of Afghanistan should provide this ground for them. Discriminate with ethnic and religious minorities in Afghanistan's history, nothing created except increase and continued of political and social tensions; The Afghan government must learn from these bitter historical experiences and provides the ground to increase political, cultural, religious, and social pluralism (Mudaber, 2016).

\subsection{Profession and Art}

Sale of Greek drugs is one of the major professions of these Afghan citizens. Most of the Sikhs and Hindus in Afghanistan have the store of plants and Greek drugs. A number of them provide their lives by another professions such as: photography, computerization, business and selling foods (Bush \& Hyde, 1995).

\section{Conclusion}

What is mentioned in the sense of the result is the couches, including the old ethnics of this land, and is of particular customs and traditional assets, as well as these Ethnic's property assets, prophets, guides and leaders, are still distinct education and interpretations in their religion Etnick Sikers in Afghanistan are also drawing and special traditions. The couches have a strong, high, powerful, and brave physiology, powerful, powerful, and brave. When the British brought India under his realm, the chose soldiers from Sikhs used them in wars, and they were always worth a lot. This topic also applies in our country, because the couches played a major role in the macro decisions of governments, if the Senator and the parliamentary representative began to participate in the counsel and ministry. The tribes with other tribes are widely thoughtful that this is the following: leaving the hair of the face, with the shoulder of the shoulder, wearing their hair, wearing shorts, having an iron bracelet, and the sword. At the time of Souneo, the Asian spots, such as Hong Dumb, Sang, Singapore, Burma, East of Iran, and Afghanistan... are engaged in business and shopkeeping.

\section{Conflicts of Interest}

The author declares no conflicts of interest regarding the publication of this paper. 


\section{References}

Amin, R. (2007). Religion of Sikh. Typed Monograph in Faculty of Social Science, Kaul University.

Ashor, D. (2001). We Are the Ancient Inhabitants of This Land "A Book about the History of Hindu, Sikh and Their Sects in Afghanistan". Stockholm: Publication of Stockholm of Swedish, Admin Wega Kabul Nat.

Barzin, L. (2006). Brief History of Buddhism and Islam in Afghanistan. Translated by Sajan Hamdani on the Website of Barzin by Persian.

Bush, R., \& Hyde, C. D. (1995). Religions in the Nowadays Society (Translated by Abdul Rawoof Gowahi, Vol. 1). Tehran: Publications of Amir Kabir.

Chahardehi, N. (1984). About Recognitions of Sikhs (Vol. 2). Kabul: Governmental Publication.

Godarzay, M. (1984). Religions Experience of Human Kind (Vol. 1). Tehran: Publication of Qaqnawis.

Heyoum, R. (1990). Live Religions of the World (Translated by Abdul Rahim Gowahi). Tehran: Publication of Fanoos.

Jehati, M. (2001). Recognition of Contemporary Religions and Religious (Translated by Mohammad Atayee). Tehran: Publications of Semat.

Mudaber, M. (2016). Celebration of Visac and Problems of Minorities in Afghanistan. On the Daily Newspaper of Our Afghanistan. Wednesday, 24th of Hamal.

Popal, K. (2000). Customs of Hindu in Afghanistan. Wikipedia Website.

Popal, K. (2009). "Race and Nationalities of Afghanistan” Sikha and Hindu. Kabul Net Site.

Rezayee, A. A. (2001). History of World's Religions (Vol. 2). Peshawar: Publication of Alzahr.

Tawqifi, H. (2004). Acquaintance to Big Religions. Tehran: Publications of Donya-e-Ketab. 